\title{
Good teacher, good tutor
}

This article was published in the following Dove Press journal:

Advances in Medical Education and Practice

II July 2016

Number of times this article has been viewed

\section{Lucélio B Couto \\ Gustavo S Romão \\ Reinaldo B Bestetti \\ Department of Medicine, University of Ribeirão Preto, Ribeirão Preto, Brazil}

Correspondence: Reinaldo B Bestetti Department of Medicine, University of Ribeirão Preto, Av. Costabile Romano, 220I, Ribeirão Preto I4096-900, Brazil Email: rbestetti44@gmail.com

\section{Dear editor}

We have read with great interest the paper by Kassab et $\mathrm{al}^{1}$, who have essentially shown that good teachers will be good tutors in a problem-based learning (PBL) environment. We have been facing great difficulties to select tutors because there has been no tradition in PBL in our region in the preuniversity teaching. Furthermore, the majority of our teachers have been formed in a discipline-based medical curriculum. ${ }^{2}$ Therefore, it is reassuring to learn from the work by Kassab et $\mathrm{al}^{1}$ that subject-matter mastery is the powerful independent predictor of tutoring skills.

This fact parallels, at least in part, our students' positive opinion about the impact of subject-matter expert tutors to guide the learning process, thus helping them to construct their medical learning. ${ }^{3}$ In fact, it has been demonstrated that self-directed study is the most important part of the tutorial session, which leads to retention of knowledge in long-term memory. ${ }^{4}$ Therefore, good teachers, by activating prior knowledge and making clear gaps in knowledge through interactive lessons and by encouraging learning based on their experience on the subject during lectures, will certainly have enough competence to motivate students to seek information in self-directed study to solve problems in tutorial sessions.

Lectures are not commonly delivered in PBL medical teaching approach. Kassab et $\mathrm{al}^{1}$ also support our view that lectures may help to promote learning in a PBL environment. In our course, we have provided students with selected lectures at the pre-clerkship stage. Importantly, such lectures have been delivered following the reporting phase of a tutorial session in the problem-solving process, usually four classes per module, and summarize the concepts related to the problems at hand. In this situation, apart from the discussion and integration of new acquired learning in the problem-solving process, students still have to undergo a written assessment through multiple-choice tests following the reporting phase, which by itself drives learning. ${ }^{5}$ Therefore, at the time of a lecture, students have a great deal of intrinsic motivation to attend such classes and to learn.

Another important point that deserves further consideration is the association of teacher's capacity of creating a relaxed atmosphere during a lecture and tutoring skills. ${ }^{1}$ This teacher will certainly be able to stimulate a favorable environment during 
a tutorial session for learning. In addition, by more interaction and better communication with students, he or she will lead to a favorable learning process. ${ }^{6}$ The same can be said regarding the ability of a lecturer to use audiovisual aids, another independent predictor of tutoring skills. As Kassab et al $^{1}$ suggest, teachers who use audiovisual guides in lectures can help students to structure knowledge by constructing concept maps. This is very important because not all schools rely on this step in the tutorial session. We have been using this tool over the last 12 years, and the data by Kassab et $\mathrm{al}^{1}$ lend support to this approach. In conclusion, the paper by Kassab et al $^{1}$ shows that good teachers will be good tutors. We agree with that.

\section{Author contribution}

All authors elaborated, designed, drafted, revised, and approved the final version of the manuscript.

\section{Disclosure}

The authors report no conflicts of interest in this communication.

\section{References}

1 Kassab SE, Hassan N, Abu-Hijleh MF, Sequeira RP. Lecturing skills as predictors of tutoring skills in a problem-based medical curriculum. $A d v$ Med Educ Pract. 2016;7:1-6.

2. Bestetti RB, Couto LB, Romão GS, Araújo GT, Restini CAB. Contextual considerations in implementing problem-based learning approaches in a Brazilian medical curriculum: the UNAERP experience. Med Educ Online. 2014;19:24366.

3. Couto LB, Bestetti RB, Restini CAB, Faria-Jr M, Romão GS. Brazilian medical students' perceptions of expert versus non-expert facilitators in a (non) problem-based learning environment. Med Educ Online. 2015;20:26893.

4. Yew EHJ, Chng E, Schmidt HG. Is learning in problem-based learning cumulative? Adv Health Sci Educ Theory Pract. 2011;16(4):449-464.

5. Wilkes M, Bligh J. Evaluating educational interventions. $\mathrm{Br}$ Med $\mathrm{J}$. 1999;318(7193):1269-1272.

6. Schmidt HG, Moust JHC. What makes a tutor effective? A structuralequations modeling approach to learning in problem-based curricula. Acad Med. 1995;70(8):708-714. 


\section{Authors' reply}

Salah Eldin Kassab'

Nahla Hassan'

Marwan Abu-Hijleh ${ }^{2}$

Reginald P Sequeira ${ }^{3}$

'Department of Medical Education, Faculty of Medicine, Suez Canal University, Ismailia, Egypt; ${ }^{2}$ Department of Basic Medical Sciences, College of Medicine, Qatar University, Doha, Qatar; ${ }^{3}$ College of Medicine and Medical Sciences, Arabian Gulf University, Kingdom of Bahrain

Correspondence: Salah Eldin Kassab

Department of Medical Education, Faculty of Medicine, Suez Canal University, PO Box 4I I I I, Ring Road, Ismailia, Egypt

Fax +20 643208543

Email: kassabse@gmail.com

\section{Dear editor}

We have read with great interest the Letter to the Editor by Couto et al in this issue about our previously published manuscript. ${ }^{1}$ We were reassured by the interesting thoughts they raised about our manuscript, which strongly endorsed our findings and corroborated their previously published research in the same area. ${ }^{2}$ In that context, we would like to emphasize that the role of the problem-based learning (PBL) tutor is considered as one of the 12 key roles of any university teacher. ${ }^{3}$ In PBL programs, lectures play a different role than in traditional curricula being considered as a learning resource for prompting students' learning. In addition, the role of teacher versus tutor (small-group facilitator) should be viewed as a continuum, with shared skills common to each other, and not be viewed as bipolar. For example, the ability to integrate knowledge is a common feature needed for planning the lecture, and also by PBL tutors through directing a tutorial group to link the different concepts related to the problem of the week by encouraging concept mapping. ${ }^{4}$

Tutoring in PBL programs is a complex process that needs special skills and techniques. Therefore, recruiting skilled PBL class tutors is one of the challenges in any PBL program. Although subject-matter mastery is one of the predictors for tutoring skills, process expertise is a sine qua non for a PBL tutor. However, a good tutor should balance the "process expertise" with the "content expertise" to conduct a successful PBL tutorial, an intuitive decision in response to the learner needs or learner participation in the classroom. Switching roles between lecturing and tutoring and the implicit conceptions and/or attitudes of some teachers toward the PBL philosophy and how it is implemented remain a challenging task for innovative medical schools.

The findings in our study can also open avenues for future practice and research. First, defining who is a good teacher in PBL programs is still fuzzy and requires the development of instruments with good psychometric properties in order to enhance the research in this area. Second, a paradigm shift in faculty development programs in PBL is essential. Faculty need to be trained in their role as lecturers as well as smallgroup tutors with great emphasis on the aspects of lecturing skills that predict the PBL tutoring skills. For example, how to maintain a relaxed atmosphere in the classroom, whether in small or large groups, needs to be part of the faculty training in PBL programs. Finally, teaching subject matter in PBL programs must be integrated with approaches, such as metacognitive activities, to enhance the degree to which students will transfer their new learning to other settings. ${ }^{5}$

\section{Author contribution}

All authors contributed to the drafting and critical revision, and approved the final version of this paper.

\section{Disclosure}

The authors report no conflicts of interest in this communication.

\section{References}

1. Kassab S, Hassan N, Abu-Hijleh M, Sequeira RP. Lecturing skills as predictors of tutoring skills in a problem-based medical curriculum. $A d v$ Med Educ Pract. 2016;7:1-6.

2. Couto LB, Bestetti RB, Restini CAB, Faria-Jr M, Romão GS. Brazilian medical students' perceptions of expert versus non-expert facilitators in a (non) problem-based learning environment. Med Educ Online. 2015;20:26893.

3. Harden RM, Crosby J. AMEE Guide No 20: The good teacher is more than a lecturer: the twelve roles of the teacher. Med Teach. 2000; 22(4):334-347.

4. Kassab S, Hussain S. Concept mapping assessment in a problem-based medical curriculum. Med Teach. 2010;32(11):926-931.

5. Bransford JD, Brown AL, Cocking RR, editors. Learning and transfer (Chapter 3). In: How People Learn: Brain, Mind, Experience, and School. Washington, DC: National Academy Press; 2000:51-78. Available from: http://books.nap.edu/html/howpeople1. Accessed June 16, 2016. 
Dove Medical Press encourages responsible, free and frank academic debate. The content of the Advances in Medical Education and Practice 'letters to the editor' section does not necessarily represent the views of Dove Medical Press, its officers, agents, employees, related entities or the Advances in Medical Education and Practice editors. While all reasonable steps have been taken to confirm the content of each letter, Dove Medical Press accepts no liability in respect of the content of any letter, nor is it responsible for the content and accuracy of any letter to the editor.

Advances in Medical Education and Practice

Dovepress

\section{Publish your work in this journal}

Advances in Medical Education and Practice is an international, peerreviewed, open access journal that aims to present and publish research on Medical Education covering medical, dental, nursing and allied health care professional education. The journal covers undergraduate education, postgraduate training and continuing medical education

including emerging trends and innovative models linking education, research, and health care services. The manuscript management system is completely online and includes a very quick and fair peer-review system. Visit http://www.dovepress.com/testimonials.php to read real quotes from published authors.

Submit your manuscript here: http://www.dovepress.com/advances-in-medical-education-and-practice-journa 